\title{
Housing Tenure Effects on Child's Educational Performance in Non-Residential Secondary Schools in Ogun State, Nigeria
}

\author{
Mike I. Anyakora ${ }^{1} \quad$ Iyanuloluwa T. Ogunsanya ${ }^{2} \quad$ Chinwe N. Odimegwu $^{1} \quad$ Edmund C.Nwakoby ${ }^{1}$ \\ 1. Chukwuemeka Odumegwu Ojukwu University, Anambra State, Nigeria, Department of Estate Management \\ 2. University of Lagos, Nigeria. Department of Estate Management
}

\begin{abstract}
This study examined the effects of housing tenure on child's educational performance in non- residential secondary school system in Ogun State, Nigeria, and it provides vital information to aid families' optimal decisions on pro-child's educational performance school accommodation arrangement. The Null hypothesis $\left(\mathrm{H}_{0)}\right.$ : there is no significant difference between home owner and non - home owner child's educational performance in non - residential secondary schools in Ogun State, Nigeria was tested using, independent sample t-test statistic, and data gathered from two sets of questionnaire consisting of 391 and 170 copies administered to day students and parents respectively in nine selected secondary schools from three local government areas in Ogun State, Nigeria using random sampling technique. Frequency tables, mean item score statistics were also used for descriptive analysis. The study discovered that significant differences exist between home owner and non - home owner child's educational performance in non - residential secondary schools in Ogun State, Nigeria with the students from home owner occupied families on one hand performing better (on a 5 points equidistant Likert Scale in which 1 = Very Poor, 2 = Poor, 3 = Average, $4=$ Good, and 5 =Very Good, $p<0.001 @ 95 \%$ confidence level) in arts subjects (mean score $=4.51$ ), science subjects (mean score $=4.35$ ), and junior secondary school (mean $=3.98$ ) than their colleagues from tenancy occupied homes that scored mean values of $2.31,3.48$, and 3.49 in the same subject areas respectively. While on the other hand, students from tenancy occupied families performed better (mean score $=4.12$ ) in commercial subjects than their colleagues home owner occupied families that obtained mean score value of 3.26 in the same subject area.This study has presented contextual knowledge on the linkages between child's educational performance and housing tenure from the outcome of the data analysis, it however, did not consider the quality of school teachers, teaching methods used and the quality of the learning environment all of which could significantly contribute to child's academic performance. The study expands the frontiers of knowledge on the benefits of home ownership as the findings could enable parents/guardians to relate better with secondary school day students in domestic chores as well as being conscious of the impact of involving day students in family business on academic performance in school. This paper is original and fills a gap in knowledge as it draws for the first time in Nigeria, the attention of parents/guardians to the impact of housing tenure on child's educational performance especially in specific subject areas.
\end{abstract}

Keywords: Home ownership, Housing Tenure, Child's Academic Performance, Ogun State Nigeria

DOI: $10.7176 / \mathrm{DCS} / 10-12-06$

Publication date: December $31^{\text {st }} 2020$

\section{Introduction}

Housing tenure refers to the legal status of occupants of residential accommodation (Mullin and Murie, 2006). According to Turner (2005) countries around the world regardless of their level of economic development exhibit a wide range of housing tenures. Housing tenure obtainable in a country reflects the nature of the housing policy and housing development programmes practiced in the country (Tadesse, 2000).

Previous studies have examined various aspects of housing tenure. For example, Green and Malpezzi (2003) examined the nature of housing tenure obtainable in families and noted that tenure is seen by families as a dichotomous choice, that is; households either rent or own their residential property. It is important to clarify on one hand that home ownership considered in housing tenure discussions includes homes owned out rightly or through subsisting mortgage borrowing; while renting on the other hand includes social and private tenancy housing types. Consequently, tenure typologies are classified to include but not limited to owner occupier and tenancy occupation. In fact, squatter occupation is yet another type, although it is considered to be an inferior tenure often without a legally enforceable right and as such is not considered in this study.

Although, home ownership has rightly been presented as the best form of access to human shelter when compared with renting and social housing (Perin, 1977 cited in Shlay, 2006; Carliner, 1998; Peterside, 2008; Zenou, 2011, Dunning, 2015 \& Anyakora, Nubi and Fagbohungbe, 2016); the actual housing tenure achieved by a family may be dependent on socio-economic status attained by the family. Following similar line of thought, Frogner (2012) assessed socio-economic structures and housing tenures in families and revealed that the specific housing tenure associated with families varies with demographic factors such as age, education, occupation, ethnicity and type of household. Nevertheless, each of the housing tenure types - owner occupier, tenancy and 
squatter occupation could be connected with a definite form of socio-economic outcome in a specific geographical location within a country. As such, existing studies in other climes have examined some aspects of the beneficial outcomes of certain housing tenure type, particularly; home ownership. For instance, at the social level, home owners in U.S.A and Germany are reported to exhibit higher degree of care and responsibility (DiPasquale and Glaeser, 1998). While at household level, home ownership was also found to be associated with child educational outcome, and family economic stability (Clinton, 1994; Green \& White, 1997; Harkness \& Newman, 2003; Whelan 2017).

However, in Nigerian research space, very little of similar information on the impacts of home ownership on various aspects of the people's lives is available for decision making and reference purposes. These researchers observed that absence of such important information, could lead to sub-optimal outcomes in households' developmental decisions, which invariably may impact on the overall national development of the country as households are the building blocks of a nation. In line with the above logic, there is the need to find out the empirical relationship between housing tenures and child educational performance. This study theorized that in developing countries such as Nigeria, owning a home may have similar impacts on families as obtains in advanced countries earlier highlighted. Perhaps the peculiar challenges of urban environment (traffic congestion, noise pollution, poor water and electricity supply situations etc.) in developing countries could mitigate the expected tenure effects on child's educational performance in a non- residential secondary school system in urban centres or, it could completely alter the effects. However, none of the above opinions have been empirically considered in existing literature. Moreover, Nigeria has both boarding and non-boarding (day school) arrangements in the secondary school education system of the country. A day school is an institution where children or high-school age adolescents are given educational instruction during the day; after which they return to their homes. UNESCO (2010) opined that day school students attend and stay in school during the school hours of the school days often with facilities for taking lunch in the school. Furthermore, UNESCO (2010) remarked that day school creates the possibility for a healthy home environment and parental care for secondary school day students. Odebunmi (1988) and Epstein (1995) agreed that students in day schools grow with parental care as students and parents are in daily contact with each other in this form of secondary school arrangement. It is easy to correct and guide a child in close proximity, and close proximity obtains in day school system. Students in day schools are able to help parents with household chores, although over indulgence in domestic work may work against the drive for good academic performance. Day students may tend to be better adjusted to the realities of their family cultures and life generally. The manners and social skills which students acquire help them to develop talents in leadership, as well as learning to adapt to difficult situations. It could be argued that while parental care may not provide mutually exclusive effects on child academic performance, house tenure may do so, because home owner occupiers tend to have ample space often with better ambience than renters.

Parents/guardians usually decide whether their children or wards will attend a boarding or non-boarding school based on specific value considerations e.g. affordability, child's educational performance outcome etc. Without researched information from academic study of this nature, most parents/guardians desiring good child's educational performance may unknowingly take anti child's educational performance decisions on child's secondary school accommodation arrangement. As it has been established in literature, that assorted housing tenure types exist; and that each has a different set of social outcomes; this study hypothesized that housing tenure impacts child's educational performance in non-boarding (day school) secondary school system. Against the preceding assumption, this study examined how different housing tenure types influence child's educational performance in a non - residential secondary school system, with a view to providing parents/guardians with vital information for making decisions on accommodation arrangement which could promote child's secondary school performance in urban centres in Nigeria. In pursuit of the above aim, the objective put forward was to compare secondary school students' performance between homeowner occupied and tenancy occupied families in a non- residential secondary school in Ogun State, Nigeria.

\section{Literature Review and Contextual Issues}

Shelter is one of the basic needs of man, others being food and clothing (Maslow, 1943). Shelter is more than just a place of habitation, but a dwelling place with all the supporting facilities and quality environment that promote modern day living. Anyakora (2016) revealed that home ownership is the preferred mode of accessing dwelling place among most families in Nigeria; hence it is the dream of an average Nigerian family to own a home. Home ownership has been associated with many benefits in literature (Green \& White 1997; DisPasquale \& Glaeser 1999; Engelhardt, Eriksen, Gale \& Mills 2003; Carasso, Bell, Olsen \& Steuerle, 2005; Anyakora, Nubi \& Fagbohungbe, 2016). Therefore, the importance of home ownership to mankind cannot be underestimated. The term home ownership according to Ogunnaike (2016), is defined as a form of housing tenure in which a person (or a group of persons) owns housing property such as a flat accommodation or a whole house either by purchase, or by direct construction with corresponding bundles of rights of ownership.

Home ownership in this discussion is contextually synonymous with owner-occupier. In families, the drive 
to become an owner occupier is propelled by the desire to: be free from rental challenges, attain improved quality of life and secure peaceful habitation without being accountable to a third party landlord except to the laws of the land. Home ownership has important economic implications for the society and the individuals. Dunning (2015) noted that home ownership generates a great deal of economic activities in a country; for example, construction industry employment and landscaping. Clinton (1994) also viewed the impact of home ownership on the lives of working-class families in United States of America (U.S.A) from the preceding perspective; and concluded that, home ownership connotes socio-economic importance to households as it economically strengthens families among other benefits. In U.S.A, most families commence wealth accumulation through home ownership on the belief that with home ownership they could have access to other good things of life e.g. better child education (Scalon \& Page-Adam, 2011).

Monitoring and coaching of students is very important in order to achieve good academic performance. Literate parents/guardians play important roles in this respect, particularly in a day school system; if they are not very busy career people. In the case of illiterate parents, direct personal monitoring and coaching of students may be problematic, although, it can still be done through the use of home lesson teachers. Busy parents/guardians also resort to home teachers in other to achieve the same goal, but in the case of boarding schools, the school usually fills this gap through extra school lessons. The last two options for supportive extra lessons for secondary school students entail payment of additional fees. Ability to pay additional fees for extra lesson largely depends on the economic disposition of the parent/guardian. Normatively, home owner parents/guardians would be expected to be more disposed to bearing such important additional cost of child education than non - home owners. Nieuwdorp (2006) advised that use of a structured monitoring system could help in improving day student's school performance. Day-schools in Nigeria tend to enroll more students than boarding schools of similar status, because day schools have lower school fees structure than boarding schools. Lower school fees rates of day schools increases affordability profile of the parents/guardians. Consequently, parents desirous of less costly schooling arrangement are attracted to sending their children to day school. Large student population in secondary school calls for higher management skills and shortage of this in schools with large population may lower efficiency and academic performance. This study supports the strategic use of structured home lesson system to improve day school child academic performance.

Academic performance refers to the level of performance in school accomplishment or success in school, Aremu and Oluwole (2001) remarked that academic performance is the core of educational growth. Jansen (2004) defined academic performance as the process of developing the capacities and potentials of the individual student so as to prepare that individual to be successful in a specific society or culture.

The child academic performance cannot be separated from the home environment in which the child grows up (Fantuzzo et al., 2000). Numerous studies revealed that various factors are responsible for scholastic failure of students, such as low socio-economic background, student's cognitive abilities, school related factors, environment of the home, or the support given by the parents and other family members (Khan \& Malik, 1999; Fan, 2001; Gonzalez-Pienda et al., 2002). Parental socio - economic characteristics to a greater extent determine student's performance in school and their adjustment to life (Aikens et al., 2008). Family financial resource is associated with parents' occupation and educational attainment; and it often implies increased learning opportunities for the children both at home and in school. Indeed, family background is the foundation for children's development, as such family background in terms of family type, size, socio-economic status and educational background play important role in children's educational attainment and social integration (Ushie et al., 2012).

In foreign scene, theoretical evidence suggests that home ownership has positive impacts on child wellbeing (Green \& White, 1997; Boehm \& Schlottmann, 1999; Haurin et al., 2002; Harkness \& Newman, 2003). The relationship between home ownership and child's outcome is well documented in literature as home ownership is linked to many positive child's outcomes, including better health, fewer behavioral problems, greater academic achievement (e.g. performance in Mathematics and Reading), lower high school dropout rates, higher level of educational attainment by age 25 , and are more likely to graduate from high school (Boehm \& schlottman 1999; Green \& White 1997; Haurin, Parcel, \& Haurin, 2002). Furthermore, Green and White (1997); Boehm and Schlottman (1999); Aaronson (2000); and Haurin, Parcel, and Haurin (2000) were of the consensus that growing up in a home owning family exerts positive effects on children's development and outcomes. However, on a somewhat contrary stance; Harkness and Newman (2003) argued that in some cases home ownership as a component of family assets could have negative impact on family welfare. Harkness and Newman noted that high equity down payment regimes in mortgage lending practices and maintenance costs could dry up family resources that could have been invested on the children. Paradoxically, under such condition, the home may not be rightly classified as an asset; since in the context of financial knowledge an asset brings surplus income in excess of liabilities (Kiyosaky \& Lecter, 2002).

It is important to explore similar vital information in Nigerian locality to aid family welfare planning and to generally improve home ownership understanding among Nigerians. Over a period of time, it has been observed 
that students exposed to the same lessons by the same teachers perform differently when they are evaluated (Adesehinwa \& Aremu, 2013). This shows that beyond the school environment, other factors could influence students' academic performance.

However, what accounts for these positive effects and whether other features may either strengthen or weaken them, is still unclear.

In Lagos and Ogun States like in most other administrative states in Nigeria, owning of properties such as land and houses is very common in rural areas. Home ownership in the rural areas is made possible for many people due to inheritance structure, However, such is not the case in most urban centres where land market forces, building regulations and development control measures among other factors usually pose huge challenges to home ownership to most families. Consequently, despite the huge benefits of home owner occupation, home ownership in the urban centres is still low (about 11\%) among Nigerians (Ayedun and Oluwatobi, 2011). The figure of $11 \%$ of home owner occupiers in Nigeria sharply contrasts against those of other countries: Singapore $(92 \%)$, USA (72\%) UK (78\%), China (60\%) and Korea (54\%). The poor home ownership level among Nigerian population explains why most of the low and middle income households resort to tenancy occupation in urban centres in Nigeria.

Education at secondary school level is expected to be the bedrock for advanced learning in tertiary institutions (Asikhai, 2010). Iriti and Bickel (2010) asserted that a well-educated and engaged citizenry is central to the socio - economic health and the stability of a democratic society. However, it takes an active synergy of harmonized government, family and community efforts to design, implement and achieve effective child secondary school education in any country. Consequently, child education is generally considered to be an important household aspiration in most countries; to the extent that it usually attracts government budgetary allocations on annual basis. Formal education plays a crucial role in addressing the goal of broader social participation by the graduating students (Iriti \& Bickel, 2010). Schools are agents of development and socialisation, but they do not exist as an end on their own but rather as a means to an end.

Considering the huge resources invested in child education by households and government alike it is important that both institutions perceive child education as an investment opportunity to be used as a means of achieving rapid economic, social, political, technological, scientific and cultural development in a country. However, the current level of investment in this important sector in most developing countries is yet to provide conducive learning environment in most secondary schools. For example, Moja (2000) observed that school environment in Nigeria is generally not conducive to learning due to the physical condition of most schools and lack of teaching and learning resources. Nevertheless, policy makers in various countries generally develop broad range of policies and programmes to deliver effective child education to the people. World Bank (2006) remarked that although, many of her client countries have increased efforts at expanding and strengthening their secondary education systems, many challenges still confront most of the countries in this vital sector. Some of the challenges confronting the countries may be in the area of households' wrong choice in child's educational decisions. Wrong decisions in any area of child's educational arrangement will likely mitigate the expected role of secondary education in the life of youths. Secondary education is intended to play dual roles of: providing skills, knowledge, and technical training for youths planning to enter the labour force, while at the same time prepares others for continuing their studies at the tertiary level of education. World Bank (2006) lamented that secondary education in most developing countries often fulfils neither of the expected roles particularly when the graduates of the school systems are exposed to either external examination or to competitive job selection processes in the labour market. External examination and job competition in the labour market are the real world student's school performance and knowledge acquisition test; the academic assessment usually starts the trend of testing the students in the school.

According to Nwokocha and Amadike (2005) academic performance of students is the yardstick for testing the educational quality of a nation. In Nigeria, public examinations such as Senior School Certificate Examination (S.S.C.E.) is one of the widely acceptable ways of measuring students' secondary school educational performance on a common platform. The other public examinations are National Examination Council (NECO) and National Business and Technical Examination Board Certificate (NABTEB) etc.

In order to equip students with the ability to contribute effectively to national development in their future career life, the academic pedagogy, learning and evaluation which produce the student ought to be very robust with wide knowledge base and far reaching depth. Needham, Crosnoe and Muller (2004) suggest that academic performance, including academic failure, is often viewed wrongly in narrow terms, as an individual behavior limited to the early life course. However, academic performance has implications that play out across life stages and on multiple levels, and researchers have revealed many factors that drive academic performance. For example, concerning the implications of academic performance; Miller (1998), Rosenbaum, DeLuca, and Miller (1999) and Crosnoe (2002b) confirmed that on the individual level, academic struggles predict short-term problem behavior and dropout, and can delay or even derail educational and occupational trajectories well into adulthood. Researchers have explored the propellants of academic performance and concluded that the factors 
include: learning attitudes, availability of learning resources, available leadership resources, available teaching skills and competencies, quality of the learning environment, parent's supportive role in the learning process, available social infrastructure, psychological and health related factors, inter- student synergy in learning, visual and hearing impairments, quality of available counselling and guidance services, home environment, time management skills, teaching and learning methods in use, development of study skills, approachability and professionalism among the teachers (Maina, 2010; Kudari, 2016; Srinivas, \& Venkatkrishnan, 2016; Maganga, 2016).

Analysis of tenure effect on child educational performance provides a proactive thinking for preventing the possibility of widespread academic failure. Widespread academic failure at the secondary education level is a far reaching social phenomenon which has been found in existing literature to correlate with fertility, mortality, marriage, and unemployment rates through its relation to educational attainment and the development of human capital (Becker 1962; Wilson 1978; Mirowsky \& Ross 2003b).

Home ownership research in developing countries including Nigeria has identified factors of land, finance, behaviour and lifestyle and other socio-economic factors that contribute to attainment of home ownership dream (Omotola, 1980; De-Soto, 2000; Nubi, 2002; World Bank, 2002; Umezuruike, 2004; Omirin, 2004; Nubi, 2006; Olawore, 2008 \& Anyakora, 2016). What is currently lacking in academic inquiry in this vital area of study, however, is examination of the effects of home ownership on households' economy, family welfare and child's social development outcomes. The relative dearth of information on the relationship between housing tenure and child secondary school performance is unfortunate given that related literature strongly suggest the possibility that poor academic performance in secondary school could disrupt national development planning key demographic metrics.

This study therefore, speculates that housing tenure could influence child's academic performance in a nonboarding secondary school and that dearth of information on this issue in existing literature is a gap which this study is trying to fill. To explore the above speculation, null hypothesis was formulated and tested as follows: Null Hypothesis $\mathrm{H}_{0}$ : There is no significant difference between home owner occupier child's educational performance and that of a child from a tenanted home. The study contends that of the hypothesis testing will avail parents and guardians vital researched information to rely on when taking decisions on child's secondary school accommodation arrangement.

\subsection{Conceptual Framework}

The conceptual framework developed for this study as shown in Figure 1 illustrates the relationships between housing tenure, family socio-economic and student's bio-characteristics in formulating the studentship learning process associated with child educational performance outcome. This conceptual framework derived from a synthesis of theoretical reviews and this study's unique thoughts and assumptions. It consequently used the abstracted relationships to conceptualize the roles played by the three sets of factors which predicate the learning process available at homes for day students and invariably determine the child educational performance. Housing tenure was defined as dichotomous categorical variables: home owner, or tenant, while family socio-economic factors comprised of: family income, educational attainment of the family head, age of the family head, marital status, and family size. The student's bio-characteristics were collected using (Gender, Age, and Class). Information on family socio-economic factors and student's bio-characteristics were first collected as grouped discrete variables, thereafter the respondents were asked to indicate on a 5 points equidistant Likert Scale (ranging from $1=$ Not Important to 5 = Very Important) each point representing the extent to which the respondents consider each of the family socio-economic variables to be important in determining day students' educational performance. For the student's bio-characteristics, information on gender was collected as dichotomous categorical variable (male or female), while data on age and class were first collected as grouped discrete variables, thereafter the respondents were also asked to indicate on a 5 points equidistant Likert Scale ( ranging from $1=$ Not Important to 5 = Very Important) the extent to which they consider each of the student's bio-characteristic variables to be important in determining day students' educational performance. The analyses carried out in this study were based on the perceived role of the variables highlighted in this conceptual framework with the assumption that other variables remain constant and are of no effect. 


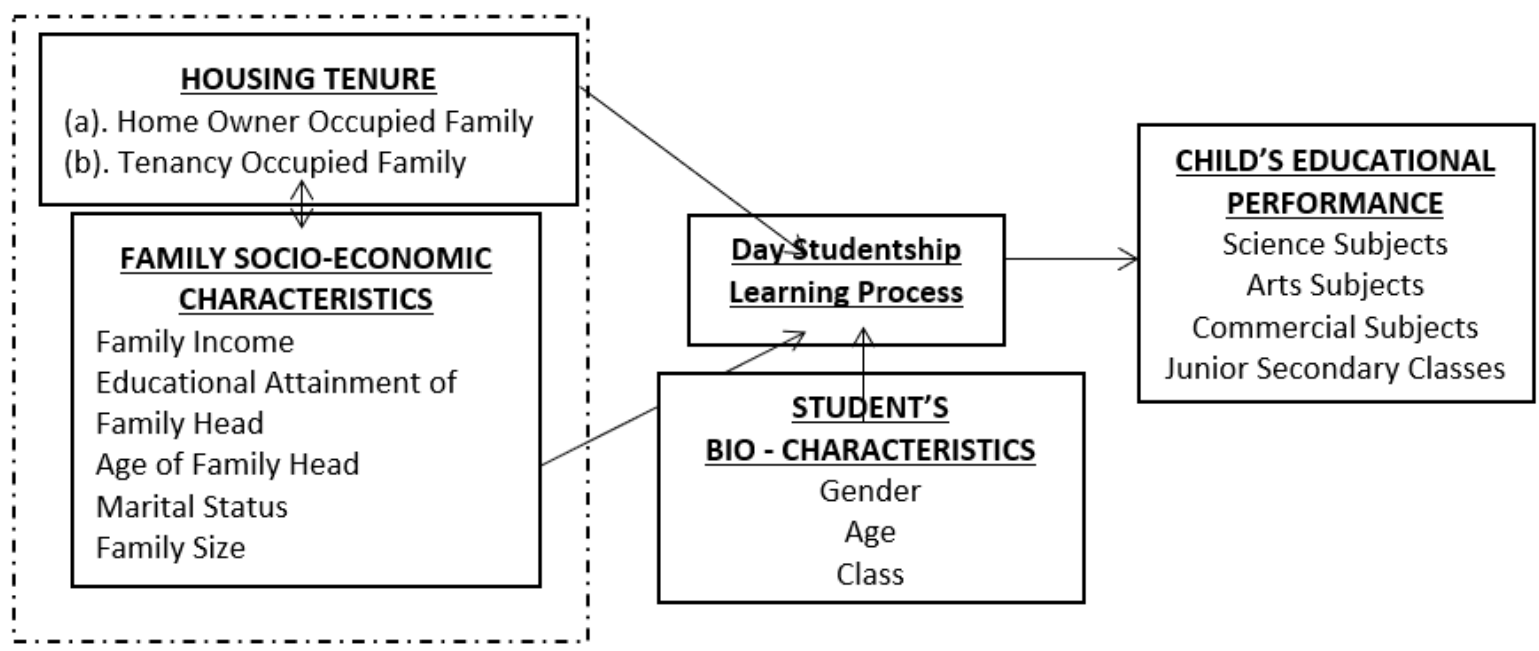

Figure1. Conceptual Framework of the Influence of Housing Tenure, and Family Socio-Economic Factors on Child's Educational Performance in Non-Residential School System.

The conceptual framework proposed that student's family housing tenure (i.e. home owner or tenant), the family's socio-economic variables, and student's bio-characteristics come into play in formulating the learning process available in day studentship. The study hypothesized that there is a relationship between families' housing tenure and child's educational performance among secondary school day students and that home owner occupier child's mean educational performance score will be higher than that of a child from a tenanted home in day secondary school system in Ogun State, Nigeria.

\section{Research Method}

This study adopted a cross-sectional survey approach taking a single shot in data collection from the respondents. The research is exploratory in nature and it used established research techniques, procedures and methods to collect and analyse information on how academic learning variables come into play with student's family housing tenure variables and the family's socio-economic variables in formulating the learning process available at home for day students in Ogun State, Nigeria.

Ogun State is the study area and its map is shown in Figure 2. Ogun State was created in 1976 in SouthWestern Nigeria. The State was named after the Ogun River which runs across the land mass of the state from north to south. It has a total land area of 16, 762 square kilometers and situates between Latitude $6.2^{\circ} \mathrm{N}$ and $7.8^{\circ} \mathrm{N}$ and Longitude $3.0^{\circ} \mathrm{E}$ and $5.0^{\circ} \mathrm{E}$. The land area of about 16,762 square kilometers of Ogun State, represents about 1.8 percent of Nigeria's total land mass of 924,000 square kilometers. Ogun state is ranked 24th largest land mass out of the 36 States in Nigeria. Ogun State has a total of twenty (20) local government areas as indicated in Figure 2. These are Abeokuta North, Abeokuta South, Ogun Water-Side, Ijebu- Ode, Ijebu North, Ijebu East, Odogbolu, Ikenne, Sagamu, Obafemi Owode, Odeda, Iffo, Ado-Odo/Ota, Egbado North, Egbado South, Ilugun Alaro, Imeko-Afon, Idarapo, Ipokia and Ewekoro. 


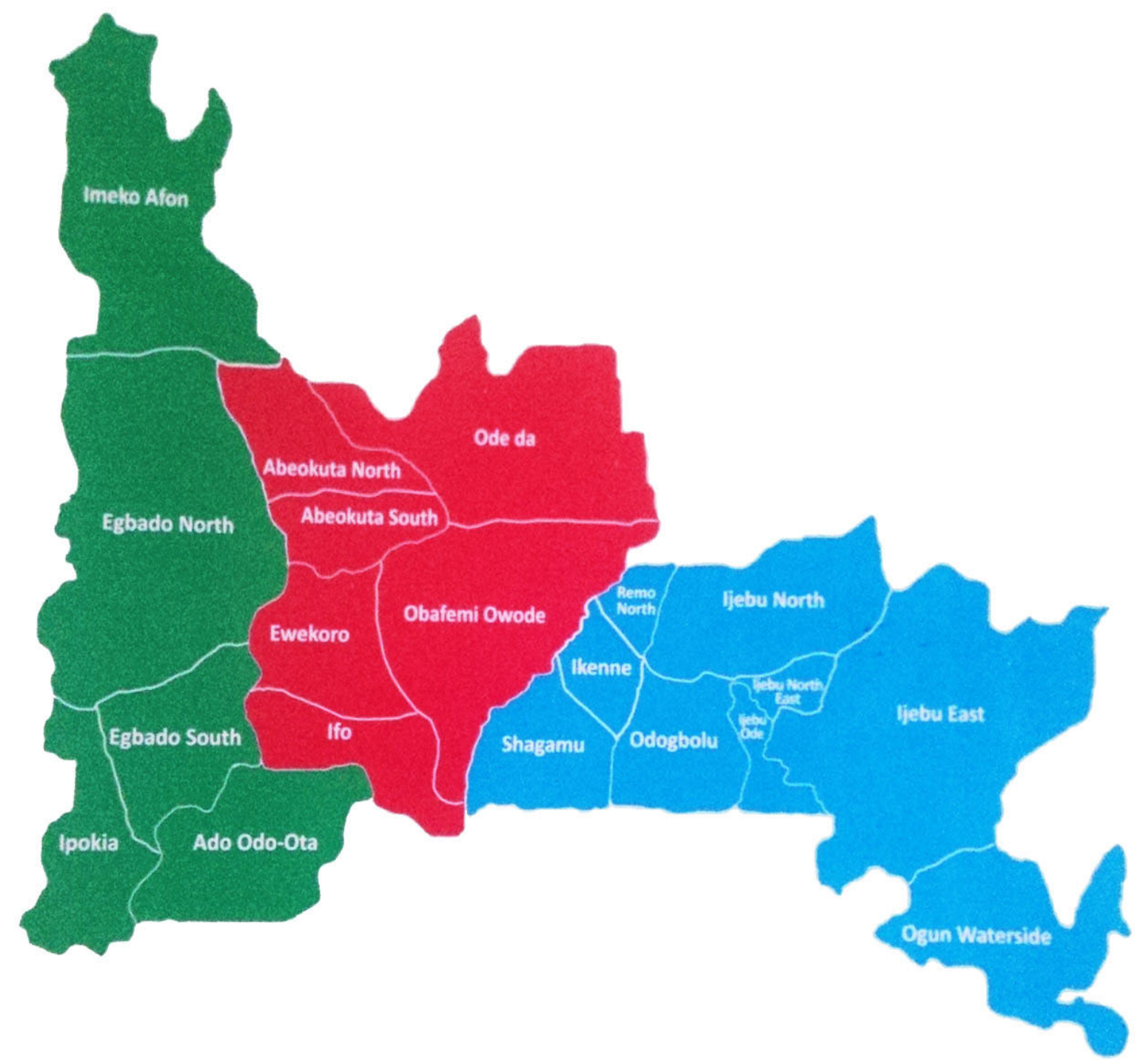

Figure 2. Administrative Map of Ogun State.

The population of Ogun State during the 1991 Census was 2,333,726. In 1991, Ogun State had a total of 578,835 households distributed unevenly across the LGAs in the State. With its growth rate of 2.83 per cent per annum, the population estimate for 2003 was projected at 3,297,408 and 3,486,683 for 2005. The population of Ogun State as at 2003 is estimated to be 3.246 million. This population comprises of 1.591 million males (49\%) and 1.655 million females (51\%). At 3.25 million, the state population is about $2.5 \%$ of the projected 2003 national population of 133 million.

The study population used for this research consists of secondary school students as well as their parents in Ogun State. Three most urbanized local government areas were purposively selected from the twenty local government areas in the state for this study. Thereafter, purposive sampling technique was further used in selecting three secondary schools with high rate of day students in each of the three local government areas making a total of nine secondary schools which were used as the sample size for this study. The total number of secondary school students in this three local government is estimated at 18,000 (Ogun State Zonal Education Board, 2018). Thus, due to the large amount of population, the required sample size (391) was calculated using Yamane (1967) statistical formula at 5\% sampling error. A total of 391 questionnaires were distributed to students in the nine schools across the three local governments, and a total of 170 questionnaires were distributed parents. The disparity in the number of questionnaire administered to the two groups arose from the fact that some parents have more than one child in day secondary school. The sample size distribution among the selected schools is shown in Table 1. 
Table 1.Sample Size Distribution among Secondary School students in Ogun State, Nigeria

\begin{tabular}{lllll}
\hline S/N & Name of School & School System & Population of Day Students & $\begin{array}{c}\text { Sample } \\
\text { Drawn }\end{array}$ \\
\hline 1 & Mayflower School Ikenne & Day/Boarding & 900 & 86 \\
2 & Ilisan High School & Day & 350 & 34 \\
3 & Babcock University High School & Day/ Boarding & 300 & 28 \\
4 & Remo Secondary School & Day/ Boarding & 600 & 58 \\
5 & Remo Baptist Academy Sagamu & Day & 200 & 19 \\
6 & Remo divisional High School & Day & 400 & 39 \\
7 & Ijebu Ode Grammer School & Day & 700 & 68 \\
8 & Adeola Odutola High School & Day & 350 & 34 \\
9 & Anglican Girls Grammar School & Day/boarding & 250 & 25 \\
& Total & & $\mathbf{4 0 5 0}$ & $\mathbf{3 9 1}$ \\
\hline
\end{tabular}

Primary data was collected from the respondents drawn from each of the nine schools using structured data gathering instrument. Two sets of data collecting instruments were designed and administered to elicit information from non-boarding secondary school students and parents respectively. The Cronbach alpha reliability coefficients were 0.880 and 0.866 respectively; implying that the instruments were good and reliable.

\section{Analysis, Results and Discussion}

Analysis in this study was based on 300 copies of returned and accepted student focused questionnaire out of 391 copies that were administered representing 76.7\% response rate and 150 copies of returned and accepted parent focused questionnaire out of 170 copies that were administered representing $88,2 \%$ response rate. Results of the analysis are presented and discussed below according to the objective and hypothesis of the study which are re-stated as; Objective: to compare home owner and non - home owner child's educational performance in non-residential secondary school in Ogun State, Nigeria and Null hypothesis $=\mathrm{H}_{0}$ : there is no significant difference between home owner and non - home owner child's educational performance in non - residential secondary school in Ogun State, Nigeria.

\subsection{Descriptive Analysis}

The result of the analyses of respondents' (students and parents) descriptive characteristics on housing tenure, socio - economic variables, and educational performance were the core of the descriptive findings of this study. Table 2 shows the respondents' characteristics of the 300 students that correctly responded to the questionnaire, it explains their gender, age and class.

Table2. Demographic Characteristics of Students

\begin{tabular}{|c|c|c|c|c|}
\hline $\mathbf{S} / \mathbf{N}$ & Variables & Levels of Variables & No of Samples (n) & Percentage (\%) \\
\hline \multirow{3}{*}{1.} & \multirow{3}{*}{ Gender } & Male & 100 & 33.3 \\
\hline & & Female & 200 & 66.7 \\
\hline & & Total & 300 & 100.0 \\
\hline \multirow{4}{*}{2.} & \multirow{4}{*}{ Age } & $10-12$ years & 16 & 5.3 \\
\hline & & 13 - 15 years & 188 & 62.7 \\
\hline & & $15-17$ years & 96 & 32.0 \\
\hline & & Total & 300 & 100.0 \\
\hline \multirow{7}{*}{3.} & \multirow{7}{*}{ Class } & JS 1 & 54 & 18.0 \\
\hline & & JS 2 & 52 & 17.3 \\
\hline & & JS 3 & 56 & 18.7 \\
\hline & & SS 1 & 54 & 18.0 \\
\hline & & SS 2 & 42 & 14.0 \\
\hline & & SS 3 & 42 & 14.0 \\
\hline & & Total & 300 & 100.0 \\
\hline
\end{tabular}

Table 2 shows that $33.3 \%$ of the students are males while $66.7 \%$ of the respondents are female. The result clearly shows female dominance in day secondary school attendance in the study area. However, this analysis did not provide enough evidence to suggest that the parents are more disposed towards female secondary school education than that of the male children, or that any form of religious or cultural practice was responsible for the observed female dominance. The table also shows that $5.3 \%$ of the respondents are between the ages of $10-12$ years, $62.7 \%$ of the respondents are between the ages of $13-15$ years and $32.0 \%$ of the respondents are between the ages of $15-17$ years. Table 2 also shows that $18 \%$ of the respondents are in JS1, $17.3 \%$ of the respondents are in JS2, $18.7 \%$ of the respondents are in JS3, 18.0\% of the respondents are in SS1, 14.0\% of the respondents are in SS2, $14.0 \%$ of the respondents are in SS3. The fact that this study elicited information from almost equal 
number of students across all levels predicates the truly representative nature of the findings of this study for secondary school students in Ogun State.

Table 3 shows the respondents' characteristics of the 150 parents that correctly responded to the questionnaire, it explains their gender, marital status, age, highest educational qualification, family size and tenure type.

Table 3. Demographic Characteristics of Parents

\begin{tabular}{|c|c|c|c|c|}
\hline $\mathbf{S} / \mathbf{N}$ & Variables & Levels of Variables & $\begin{array}{c}\text { No of } \\
\text { Samples (n) }\end{array}$ & Percentage (\%) \\
\hline 1. & Gender & $\begin{array}{l}\text { Male } \\
\text { Female } \\
\text { Total }\end{array}$ & $\begin{array}{c}100 \\
50 \\
\mathbf{1 5 0}\end{array}$ & $\begin{array}{c}66.7 \\
33.3 \\
\mathbf{1 0 0 . 0}\end{array}$ \\
\hline 2. & Marital Status & $\begin{array}{c}\text { Married } \\
\text { Divorced/Widowed/Separated } \\
\text { Total }\end{array}$ & $\begin{array}{c}140 \\
10 \\
150\end{array}$ & $\begin{array}{c}93.3 \\
6.7 \\
\mathbf{1 0 0 . 0}\end{array}$ \\
\hline 3. & Age & $\begin{array}{c}31-40 \text { years } \\
41-50 \text { years } \\
51 \text { years and above } \\
\text { Total }\end{array}$ & $\begin{array}{r}60 \\
80 \\
10 \\
\mathbf{1 5 0}\end{array}$ & $\begin{array}{c}40.0 \\
53.3 \\
6.7 \\
\mathbf{1 0 0 . 0}\end{array}$ \\
\hline 4. & $\begin{array}{c}\text { Highest } \\
\text { Educational } \\
\text { Qualification of } \\
\text { Respondent } \\
\end{array}$ & $\begin{array}{c}\mathrm{ND} / \mathrm{HND} \\
\mathrm{BSc} \\
\mathrm{MSc} / \mathrm{MBA} / \mathrm{MEd} \\
\text { Total } \\
\end{array}$ & $\begin{array}{c}40 \\
50 \\
60 \\
\mathbf{1 5 0} \\
\end{array}$ & $\begin{array}{c}26.7 \\
33.3 \\
40.0 \\
\mathbf{1 0 0 . 0}\end{array}$ \\
\hline 5. & Occupation & $\begin{array}{c}\text { Civil Servant } \\
\text { Self-Employed } \\
\text { Private Organisation } \\
\text { Total } \\
\end{array}$ & $\begin{array}{c}70 \\
50 \\
30 \\
\mathbf{1 5 0} \\
\end{array}$ & $\begin{array}{c}46.7 \\
33.3 \\
20.0 \\
\mathbf{1 0 0 . 0}\end{array}$ \\
\hline 6 & $\begin{array}{l}\text { Number of } \\
\text { Children }\end{array}$ & $\begin{array}{c}2 \\
3 \\
4 \\
\text { Total } \\
\end{array}$ & $\begin{array}{c}70 \\
50 \\
30 \\
\mathbf{1 5 0} \\
\end{array}$ & $\begin{array}{c}46.7 \\
33.3 \\
20.0 \\
\mathbf{1 0 0 . 0} \\
\end{array}$ \\
\hline 7 & Tenure Type & $\begin{array}{c}\text { Tenant } \\
\text { Home Owner Occupier } \\
\text { Total }\end{array}$ & $\begin{array}{r}122 \\
28 \\
\mathbf{1 5 0}\end{array}$ & $\begin{array}{l}81.3 \\
18.7 \\
\mathbf{1 0 0}\end{array}$ \\
\hline
\end{tabular}

Table 3 shows that most of the parents (66.7\%) that participated in this survey are males while $33.3 \%$ are females. This means that both gender types of parents were adequately represented in the study. Most of the parents $(93.3 \%)$ are validly married, but the remaining $6.7 \%$ of them consist of divorced/widowed/separated. On the age of the respondents, Table 3 shows that almost all the parents (93.3\%) are in very active young age, although the fact that majority of them (60.2\%) are in the age bracket of 41years - 51years and above suggests a degree of late marriage among the participants. It is considered adequate for this study that most of the parents that responded to the interview are still in active years and it will be reasonable to expect that parents in such age bracket will work to provide good secondary education for their children. Analysis of the responses on the highest educational attainment by the respondents shows that all the parents are educated, however, majority of them $(73.3 \%)$ are university graduates. The pattern of respondents' educational attainment suggests that they have high premium for child's good secondary school education. The Table further shows that $46.7 \%$ are civil servants, $25 \%$ are self-employed and $20.0 \%$ works with private organization. Table 3 further reveals that $46.7 \%$ of the respondents have 2 children, while $33.3 \%$ of the respondents have 3 children and $20 \%$ of the respondents have 4 children. Table 3 further reveals that $46.7 \%$ are civil servants and $33.3 \%$ are self-employed. Majority of the parents $(81.3 \%)$ are tenants while the remaining $(18.7 \%)$ are home owner occupiers. On the whole, from the information in the table, responses from the respondents are considered adequate and reliable for analysis carried out in this study.

4.1.1 Hypothesis Testing

In order to explore the difference in academic performance between secondary school day students from home owner occupied families and their counterparts from tenanted homes, the null hypothesis which stated that: there is no significant difference between home owner and non - home owner child's educational performance in non - residential secondary school in Ogun State, Nigeria was broken down into 4 sub-null hypotheses (e.g. there is no significant difference between home owner and non - home owner child's educational performance in science subjects in non - residential secondary school in Ogun State, Nigeria) in measurable academic performance 
areas of science, arts, commercial subjects and in junior secondary school for ease of analysis.

The overall students' academic performance mean scores for science, arts, commercial subjects and junior secondary school were first obtained based on the students' self - performance rating on the above highlighted subject areas using a 5 points equidistant Likert Scale in which $1=$ Very Poor, $2=$ Poor, $3=$ Average, $4=$ Good, and 5 = Very Good; while those in junior secondary school were also asked to provide an overall rating of their academic performance in junior secondary school subjects using similar scale.

Frequency count, mean, minimum and maximum statistics were first used in the analysis without considering tenure; thereafter, each of the sub-hypothesis was tested using frequency count and independentsample t-test to compare the students' academic performance in science, arts, commercial subjects and junior secondary school according to tenure types. The result of the descriptive analysis showing respondents' mean academic scores without considering difference in tenure is as shown in Table 4.

Table 4. Academic Performance Statistics for all Housing Tenures

\begin{tabular}{cccccc}
\hline & Senior & Secondary & \multicolumn{2}{c}{ Classes } & \multicolumn{2}{c}{ Junior Secondary Classes } \\
\hline Variable & $\begin{array}{c}\text { Science Students' } \\
\text { Performance }\end{array}$ & $\begin{array}{c}\text { Art Students' } \\
\text { Performance }\end{array}$ & $\begin{array}{c}\text { Commercial } \\
\text { Students' } \\
\text { Performance }\end{array}$ & $\begin{array}{c}\text { Junior Secondary } \\
\text { Students' } \\
\text { Performance }\end{array}$ & Total \\
N $\quad$ Valid & 45 & 52 & 41 & 162 & 300 \\
Mean & 3.780 & 3.925 & 3.861 & 3.667 & 1 \\
Minimum & 1 & 1 & 1 & 5.00 \\
Maximum & 5.00 & 5.00 & 5.00 & \\
\hline
\end{tabular}

In Nigeria, senior secondary students are usually classified into Science, Arts, and Commercial groups. Consequently, information in Table 4 shows that out of the 138 senior secondary students that participated in the research, 45 are in science group with overall academic performance mean score value of 3.86, and 52 students that are arts subjects based had an overall academic performance mean score value of 3.93; while the remaining 41 of the students in senior classes that are based on commercial subjects scored an overall academic performance mean score value of 3.780. This implies that senior secondary school students in the study area perform best in arts subjects (mean score $=3.93$ ) which tends to good performance on the scale, followed by commercial (mean score $=3.861$ ) and science (mean score $=3.780$ ) subjects respectively.

Further in analysis, after the information in Table 4, it became necessary to examine the respondent's performance on the basis of tenure. Thus, the result of the frequency analysis of their responses to the questions according to housing tenure is presented in Table 5.

Table 5. Students' Academic Performance According to Housing Tenure

\begin{tabular}{|c|c|c|c|c|c|c|c|}
\hline \multirow{2}{*}{\multicolumn{2}{|c|}{ Type of House }} & \multicolumn{5}{|c|}{ Science Students' Performance } & \multirow[b]{2}{*}{ Total } \\
\hline & & Very Poor & Poor & Average & Good & $\begin{array}{l}\text { Very } \\
\text { Good }\end{array}$ & \\
\hline & Tenant & 3 & 5 & 4 & 5 & 3 & 20 \\
\hline & Home owner & 2 & 1 & 3 & 10 & 9 & 25 \\
\hline Total & & 5 & 6 & 7 & 15 & 12 & 45 \\
\hline \multicolumn{8}{|c|}{ Art Students' Performance } \\
\hline & Tenant & 2 & 4 & 6 & 7 & 5 & 24 \\
\hline & Home owner & 0 & 2 & 2 & 11 & 13 & 28 \\
\hline Total & & 2 & 6 & 8 & 18 & 18 & 52 \\
\hline \multicolumn{8}{|c|}{ Commercial Students' Performance } \\
\hline & Tenant & 2 & 1 & 5 & 8 & 7 & 23 \\
\hline & Homeowner & 5 & 3 & 3 & 4 & 3 & 18 \\
\hline Total & & 7 & 4 & 8 & 12 & 10 & 41 \\
\hline \multicolumn{8}{|c|}{ Junior Secondary Students' Performance } \\
\hline & Tenant & 15 & 13 & 17 & 15 & 11 & 71 \\
\hline & Homeowner & 11 & 8 & 22 & 29 & 21 & 91 \\
\hline Total & & 26 & 21 & 49 & 70 & 43 & 162 \\
\hline
\end{tabular}

Table 5 shows that more (19) students from home owner occupied families tend to do better (i.e. good and very good ratings) than their counterparts (8) from tenancy occupied homes that also scored good and very good ratings in science subjects. Moreover, the information revealed that few (3) of the students from home owner occupied families are in very poor and poor grades contrary to (8) of their counterparts from tenancy occupied homes in the same rating in science group. Similarly, a higher number (24) of students from home owner occupied families tend to perform better (at good and very good ratings) than their counterparts (12) from 
tenancy occupied homes that also scored good and very good ratings in arts subjects, while few (2) of the students from home owner occupied families are in poor and very poor grades as against (6) of their counterparts from tenancy occupied homes in the same rating in art group. Conversely, the result established that greater number (15) of day students from tenancy occupied families perform better in commercial subjects than their counterparts (7) from home owner occupied homes in the study area. The table also shows that few (3) of the students from tenancy occupied families scored poor and very poor grades in commercial subjects than their counterparts (8) from home owner occupied families. In the case of academic performance in the junior secondary school level, higher number (50) of the students from home owner occupied families outperform (at good and very good ratings) than their counterparts (26) from tenancy occupied homes that also scored good and very good ratings.

The findings in Table 5 suggest that on one hand, day students from home owner occupied families perform better in science, and arts subjects, and also in junior secondary school than their counterparts from tenancy occupied homes; while on the other hand, the day students from tenancy occupied families perform better in commercial subjects than their counterparts from home owner occupied in Ogun State, Nigeria.

Result of the Independent Sample T-test analysis used in testing the difference between the mean score of students from home owner occupied families and those of the students from tenancy occupied homes as well as the overall mean scores without tenure considerations in science, arts, commercial and junior secondary school is presented in Table 6.

Table 6. Summary of Students' Overall Academic Performance Mean Scores Versus Mean Scores According to Tenure.

\begin{tabular}{|c|c|c|c|c|c|}
\hline Subject Areas & $\begin{array}{l}\text { Tenure Type } \\
\text { (Sub Hypothesis) }\end{array}$ & $\begin{array}{l}\text { p-value @ 95\% } \\
\text { confidence }\end{array}$ & $\begin{array}{l}\text { Mean } \\
\text { values }\end{array}$ & $\begin{array}{c}\text { Overall Mean } \\
\text { Values }\end{array}$ & Decision \\
\hline \multirow[t]{5}{*}{ Science Subjects } & $\mathrm{H}_{01} \mathrm{Sub} \_1$ & $<.001$ & & & Reject \\
\hline & Owner & & $4.35^{*}$ & 3.86 & \\
\hline & Occupied Families & & & & \\
\hline & Tenancy Occupied & & 3.48 & & \\
\hline & Families & & & & \\
\hline \multirow[t]{5}{*}{ Arts Subjects } & $\mathrm{H}_{01} \mathrm{Sub} \_2$ & $<0.001$ & & & Reject \\
\hline & Home ${ }^{-}$ & & $4.51 *$ & 3.93 & \\
\hline & Occupied Families & & & & \\
\hline & Tenancy Occupied & & 2.31 & & \\
\hline & Families & & & & \\
\hline & $\mathrm{H}_{01} \mathrm{Sub} 33$ & .000 & & & Reject \\
\hline \multirow[t]{4}{*}{ Subjects } & Owner & & 3.26 & & \\
\hline & Occupied Families & & & 3.78 & \\
\hline & Tenancy Occupied & & $4.12 *$ & & \\
\hline & Families & & & & \\
\hline Junior Secondary & $\mathrm{H}_{01} \mathrm{Sub} \_4$ & $<.001$ & & & Reject \\
\hline \multirow[t]{3}{*}{ School } & Home ${ }^{-}$ & & $3.98 *$ & 3.67 & \\
\hline & Occupied Families & & & & \\
\hline & Occupied & & 3.49 & & \\
\hline
\end{tabular}

$*=$ Indicates higher mean score value.

A cursory look at the summary of the results of analyses presented in Table 6 reveals that students from home owner occupied families tend to perform better in arts (mean score $=4.51)$, science (mean score $=4.35$ ), and junior secondary school (mean $=3.98$ ) than their colleagues from tenancy occupied homes that scored mean values of $2.31,3.48$, and 3.49 in the same subject areas respectively. Nevertheless, students from tenancy occupied families appear to be performing better (mean score $=4.12$ ) in commercial subjects than their colleagues that obtained mean score value of 3.26 in the same subject area. The difference between the academic performance of secondary school day students from home owner occupied homes and that of students from tenancy occupied families becomes more distinct when the respective mean scores of each tenure group is related to the students' overall mean score values under aggregated tenure. It is also important to note that the home owners' mean scores in arts, science, and junior secondary school were each found to be greater than the aggregated tenure mean score values $(3.98,3.86$, and 3.67) obtained in analysis in the corresponding subject areas. Similarly, the tenants' mean score in commercial subjects was also observed to be higher than the aggregated tenure mean score value of 3.78. The independent sample t- test is not statistically significant at $5 \%$ as the asymptotic significance value is less than 0.05 .

Decision: The null hypothesis $\mathrm{H}_{0}$ is not true, but the alternate hypothesis $\mathrm{H}_{1}=$ There is a significance difference between home owner and non - home owner child's educational performance in non - residential 
secondary school in Ogun State, Nigeria is true.

\section{Findings of the Study}

This study found that there are more female day students in secondary schools in the study area than there are males. This study established that day students from home owner occupied families tend to perform better in junior secondary school, arts and science subjects than their counterparts from tenancy occupied homes. On the contrary, the study further, established that secondary school day students from tenancy occupied homes in Ogun State, Nigeria out perform their counter parts from home owner occupied families in commercial subjects.

Although the state of boarding facilities in secondary schools in the study area was not directly considered in this study, however the fact that both home owner and non-home owner families opted for day studentship for their children suggests that this important facility may be either quantitatively or qualitatively inadequate in the study area or both. The problem of inadequacy in this vital socio-economic infrastructure might have brought about the need for day studentship in some families. Although, the families in the study area have different housing tenure types; nevertheless, they may have opted for day studentship for their children in the hope of providing better sanitary and learning environment at home for secondary school students. However, parents and guardians in Nigeria were never aware of the effect of tenure typology on child educational performance prior to this study.

\subsection{Implications of Findings}

The first of the implications of the findings of this study is that, it has revealed the need for educational policy action on strategic effort by the government to add quantitatively and qualitatively to existing stock of student hostels in public secondary schools in Ogun State, Nigeria. In this respect, more of female hostels should be constructed especially in mixed secondary schools as a government response to curtailing high incidence of day studentship among girls in the study area. The next far reaching implication of the findings of this study is that the knowledge made available in by this study will enable parents/guardians to now relate better with secondary school day students in domestic chores at home as well as being conscious of the impact of involving day students in family business in certain subject areas.

5.1.1 Conclusion

This study established that there is a significant relationship between housing tenure and child educational performance. Consequently, it concluded that housing tenure influences child's educational performance in nonresidential secondary school system, and that both home owner occupier and non-home owner occupier families could adapt this fact in guiding their children to excellence in certain future career paths.

\section{References}

Aaronson, D. (2000). A note on the benefits of homeownership. Journal of Urban Economics, 47(3), 356-369.

Adesehinwa O. A. \& Aremu, A. O. (2010). The relationship among predictors of child, family, school, society and the government and academic achievement of senior secondary school students in Ibadan, Nigeria. Procedia Soc. Behav. Sci. 5, $842-849$.

Aikens, N.L. \& Barbarin, O. (2008). Socioeconomic differences in reading trajectories: the contribution of family, neighborhood, and school contexts. J. Educ. Psychology, 100, 235-251.

Anyakora, M.I. (2016) Determinants of home ownership among tertiary institutions workers in Lagos State, Nigeria: A behavioural approach. An unpublished PhD thesis submitted to the University of Lagos.

Anyakora, M.I., Nubi, T.G., \& Fagbohungbe, O.B (2016). Personnel Financing Management Behaviour and Homeownership among Workers in Public Tertiary Institutions in Lagos State. Journal of Contemporary Issues in Real Estate, 2016.

Aremu O.A. \& Oluwole, D.A (2001). Gender and birth order as predictors of normal pupils' anxiety pattern in examination. Ibadan J. Educ. Studies, 1(1) 1-7.

Ashikhia, D. A. (2010). Students and teachers perceptions of the causes of poor academic performance in Ogun State Secondary Schools (Nigeria): Implication for counseling for national development. Retrieved fromhttp://www.eurojournal.com/ejss on august 28th, 2018.

Ayedun, C.A., \& Oluwatobi, A.O. (2011). Issues and Challenges Militating against the sustainability of affordable housing provision in Nigeria. Journal of business management dynamics. 23 (2), pp. 156-204.

Boehm, T.P. and Schlottmann, A.M. (1999). Does homeownership by parents have an economic impact on their children? Journal of Housing Economics, 8(3), pp. 217-232.

Carasso, A., Bell, E., Olsen, E. O. \& Steuerle, C. E. (2005). Improving Homeownership among Poor and Moderate-Income Households. The Urban Institute, no. 2, pp. 1-7.

Carliner, M.S. (1998). Development of federal homeownership policy. Housing Policy Debate 9(2). Fannie Mae Foundation 1998.

Clinton, B. (1994). The national homeownership strategy: Partners in the American dream. US Department of 


Housing and Urban from
http://www.globalurban.org/National_Homeownership_Strategy.pdf accessed on 04/03/2010.

De-Soto, H. (2000). The mystery of capital: Why capitalism triumphs in the West and fails everywhere else. Great Britain: Bantam Press.

DOI: $10.3968 /$ j.ibm.1923842012041.1125 ISSN 1923-841X[Print]. Online: ISSN 1923-8428 www.cscanada.org visited on $12 / 05 / 2013$.

Dispaquale, D. \& Glaeser, G.L. (1999). Incentives and Social Capital: Are Homeowners Better Citizens. Journal of Urban Economics, 45(2), pp. 354-384

Dunning, W. (2015). A profile of home buying in Canada. Canadian Association of Accredited Mortgage Professionals. Retrieved from caam.org/meloncms/media/Spring2015Survey Report.pdf on 24/06/2016.

Engelhardt, G.V., Eriksen, M., Gale ,W.G., and Mills G.B. (2003). What Are the Social Benefits of Homeownership? Experimental Evidence for Low-Income Households. Retrieved $27^{\text {th }}$ August,2017.Retrievedfrom https:/www.brookings.edu/wpcontent/uploads/2016/06/social benefit home

Epstein, J. L. (1995). School family community partnerships: Caring for the children we share. Phi Delta Kappa, 76, 701-702 Estate Economics, 30, pp. 635-666.

Fan, X. (2001). Parental involvement and students' academic achievement: a growth modeling analysis. $J$. Experim. Educ., 70, 27-61.

Fantuzzo, J. Tighe, E. \& Childs, S. (2000). Family involvement questionnaire: a multivariate assessment of family participation in early childhood education. J. Educ. Psychology, 92, 367-376.

Gonzalez-Pienda, J.A, Nunez, J.C., Gonzalez-Pumariega, S., Alvarez, L., Roces, C. \& Garcia, M. (2002).A structural equation model of parental involvement, motivational and aptitudinal characteristics, and academic achievement. J. Experim. Educ., 70, 257-287.

Green, R.K., \& White M J (1997). Measuring the Benefits of Home owning: Effects on Children. Journal of urban economics 4 (3), pp. 441-461.

Harkness, J. \& Newman, S. (2003a). Effects of homeownership on children: The role of neighborhood characteristics and family income. FRBNY Economic Policy Review, June: 87-107.

Harkness, J. \& Newman, S. (2003b). Differential effects of homeownership on children from higher and lower income families. Journal of housing research, 14(1), pp. 1-19.

Haurin, D.R, \& Rosenthal, S.S. (2004). The sustainability of homeownership: Factors affecting the duration of homeownership and rental spells. Housing Policy Debate 9(2). http: // spaj.ukm.my/jsb/index.php/jbp/index.html. Accessed on 13/05/2013.

Haurin, D. R., Parcel, T. L., Haurin, R. J. (2002) "Does homeownership affect child outcomes?" Real Estate Economics 30:4 (2002): 635-666.

Jansen, J.V. (2004). Taalvaardigheid as moderator in die voorspelling van akademieseprestasie: master's thesis. Bloemfontein: University of the Free State.

Khan, R.M. \& Malik, K. (1999). Effectiveness of parents' involvement in reading, child's overt behavior at home, mothers' educational level on children's reading comprehension. J. Elementary Educ., 21, 68-91.

Kiyosaki, R. T. \& Lecter, S. L. (2002). Retire young retire rich. New York: Warner Books \& Cashflow Technologies, Inc.

Kudari, J.M. (2016). Survey on the factors influencing the student's academic performance.

Maganga, J.H. (2016). Factors Affecting Student's Academic Performance: A Case Study of Maina, M.J. (2010). Strategies Employed by Secondary School Principals to Improve Academic Performance in Embu West $\begin{array}{lllll}\text { District. } & \text { Kenyatta } & \text { University. } & \text { Retrieved } & \text { August }\end{array}$ fromhttp://irlibrary.ku.ac.ke/bitstream/handle/123456789/930/Mwaura\%2C\%20James\%20 Maina.pdf?sequence $=3$

Moja, T. (2000). Nigeria education sector analysis: An analytical synthesis of perfomance and main issues. World Bank Project Appraisal Report (2000 Draft) From https://siteresources.worldbank.org/NIGERIAEXTN/Resources/ed_sec_analysis.pdf $\quad$ accessed on $22 / 11 / 2018$

Mullins, D., \& Murie, A. (2006). Housing Policy in the UK. Basingstoke: Palgrave Macmillan.

Needham, B.L., Crosnoe, R. and Muller, C. (2004). Academic failure in secondary school: The inter-related role of health problems and educational context. Soc Probl. 51(4): 569-586.

Nieuwdorp, L., (2006) De betrokkenheid van de community bij onderwijs in ontwikkelingslanden: een dossier onderzoek: The Involvement of the Community in boarding and day Education in Developmental Countries

Nubi, T.O., (2002). Housing financé in Nigeria-Need for re-engineering. [[Electronic Version]. http://www.housingfinance.org/uploads/Publicationsmanager/Africa_EFFECTIVE MOBILIZATION HOUSING-NIGERIA accessed on $12^{\text {th }}$ October, 2012.

Nubi, T.G., (2006). An assessment of the effectiveness of mortgage finance for housing procurement in selected cities of Nigeria. An unpublished PhD thesis submitted to the University of Lagos. 
Nwokocha, A., C. \& Amadike, N., F. (2005). A comparative study of academic performance in public and private secondary schools in River State. Nigerian Journal of Educational Administration and Planning. 5(2): $188-191$.

Odebunmi, A. (1988). The Effect of Home Background on Students Academic Performance. Nigeria Journal of Educational Psychology, 6(1):8-9. Piaget J 1932. The Moral Development of the Child. New York: Harcourt Brace.

Ogunnaike, A. (2017). Enhancing homeownership opportunities among middle-income earners in Nigeria: $A$ case study of Lagos Metropolis. Retrieved 23 ${ }^{\text {rd }}$ July, 2018 from: http://eprints.uwe.ac.uk/30424

Olawore, A. (2008). Housing finance options in Nigeria. Being a conference paper presented at Housing finance seminar, Lagos International Housing Conference 2008 organized by the Nigerian Institution of Estate Surveyors and Valuers (Lagos State Branch) on the $26^{\text {th }}$ of May, 2008.

Omirin, M.M. (2004). Issues in land accessibility in Nigeria. In Omirin, .M.M., Nubi, T.O., and Fawehinmi (Eds), Book of Readings: Land management and property tax reform in Nigeria, (pp 49-70). Department of Estate Management University of Lagos.

Peterside, C.S. (2008). Policy foundation for affordable housing in Nigeria. Retrieved from http://nigeriaworld.com/articles/2003/oct/140.html. Accessed on 13/3/2008.

Scanlon E, Page-Adams D. (2001). Effects of asset holding on neighborhoods, families, and children: A review of research. In: Boshara Ray., editor. Building assets: A report on the asset-development and IDA field. Washington, DC: Corporation for Enterprise Development; 2001.

Shlay, A.B. (2006). Low-income Homeownership: American Dream or Delusion? Urban Studies, 43 (3), pp. 511-531.

Srinivas, P., \& Venkatkrishnan, S. (2016). Factors Affecting Scholastic Performance in School Children. IOSR Journal of Dental and Medical Sciences, 15(7), 47-53.

Taddesse, G.G. (2000). Housing situation in Addis Ababa City: constraints and some suggestions to improve the performance of the sector, A paper discussed at the symposium on "Building a vibrant and a livable Addis Ababa, organized by Addis Ababa Chamber of commerce in collaboration with Freidrick Ebert Stiftung of Germany, Addis Ababa

Turner, M.A. (2010). New Life for US Housing and Urban Policy. Urban Research and Practice, 3 (3), pp. 328337.

UNESCO (2010) Education for all: the quality imperative, EFA Global Monitoring Report

Ushie, M.A., Onongha, G.I., Owolabi, E.O. \& Emeka, J.O. (2012). Influence of family structure on students' academic performance in Agege local government area, Lagos State, Nigeria. European J. Educ. Studies, 4, 177-187.

Whelan, S.(2017). Does homeownership affect education outcomes? IZA World of Labor: 342 doi: 10.15185/izawol.342

World Bank (2002, p. 58) Globalisation, Growth, and Poverty: Building an Inclusive World Economy. A World Bank Policy Research Report. A co-publication of the World Bank and Oxford University Press.

Zenou, Y. (2011). Housing policies in China: Issues and options. IZA Policy Paper No. 24, 1-33 